\title{
Study on e-waste (CRT TVs/monitors and washing machines) generation in Bandung
}

\author{
Nadya Humaira ${ }^{1}$, and Emenda Sembiring, ${ }^{2, *}$ \\ ${ }^{1,2}$ Environmental Engineering Study Program, Faculty of Civil and Environmental Engineering, Bandung Institute of Technology, Jl. \\ Ganesha No. 10, Bandung, West Java, Indonesia
}

\begin{abstract}
Modern day's rapid development in technology has forced a shift in trends and popularity of electronic products. This causes early obsolescence of former technologies such as cathode ray tubes (CRT), leading to massive disposal in a short amount of time. To be able to predict this newly developing waste stream, a study on the generation of such electronic waste products is needed. In a case study focusing on Bandung, questionnaires to primary sources of e-waste such as households, offices, schools and laundromats were conducted to determine not only the number of e-products that is used and discarded, but also how ewaste is treated firsthand when it becomes unwanted. The e-waste generation predicted is about 65,000 units of CRT TVs per year, 19,000 CRT monitors per year and 48,000 washing machines per year. Survey results show that when proper waste collection and recycling is implemented, CRT TVs and monitors will have been eliminated within a decade (2028 being the marking year) meanwhile the trend for washing machine consumption continues to incline up until today.
\end{abstract}

\section{Introduction}

This study focuses on specific e-products, that is CRT TVs, CRT monitors, and washing machines. The history of how such electronic products entered Bandung is not precisely known, but it can be predicted that CRT TVs became popular in the $60 \mathrm{~s}$ when TV stations were still monopolized, meanwhile CRT monitors probably became popular in the 90s when internet and computer networking was first developed by local students. Washing machines were first put into international market around 1957, meanwhile in Indonesia, it can be assumed that the product boomed between 1980-1990 when household appliance producers started to arise.

According to Widyarsana [4], sales of e-products in general continues to incline up to the year 2000, though sales and use of desktop computers began to diminish after 2005. Widyarsana [4] stated through statistics of his 2008 research findings that the average number of eproducts used in Bandung (new and secondhand) per 100 households is around $100 \mathrm{TVs}$ (CRTs and flat screens), 50 computers and 60 washing machines.

Early obsolescence of cathode ray tube products is caused by the rising popularity of new technologies such as LCD, LED and plasma screens. This shift in technology and trend eventually causes consumers to have their old electronic products disposed of, even though they may still be in good shape. Though these "old-fashioned" products have become a dying industry, they still contain materials that are valuable and can be recycled. Meanwhile, CRT products are estimated to reach the peak of disposal between 2015-2020 according to Gregory [1].

\section{Materials and method}

The study of e-waste generation in Bandung is done primarily through questionnaires sent out to (randomly picked) households, schools, offices and laundromats, and through literature or secondary data. The number of survey respondents according to their categories are given in Table 1.

The survey is done with two types of media, the first being an online questionnaire with a total number of respondents making up $75 \%$ of the number of samples needed to represent the domestic sector, and the second being door-to-door manual interviews to the remaining samples needed for households, schools, offices and laundromats. The main objective of the survey is to determine the number of electronic products (namely CRT TVs, CRT monitors and washing machines) that are and have been of use throughout Bandung, if and when such products have become unwanted (nonworking or obsolete) then discarded, and the behavior of society in handling unwanted electronics. From such data, the lifespan of e-products can be determined, and e-waste generation can be predicted using a life cycle analysis method.

\footnotetext{
* Corresponding author: emenda@ftsl.itb.ac.id
} 
Table 1. Number of survey respondents.

\begin{tabular}{|c|c|c|c|c|}
\hline $\begin{array}{l}\text { Category of } \\
\text { Respondent }\end{array}$ & $\begin{array}{l}\text { Population } \\
\text { in Bandung }\end{array}$ & $\begin{array}{c}\text { Confidence } \\
\text { Level }\end{array}$ & $\begin{array}{l}\text { Number of } \\
\text { Samples }\end{array}$ & Description \\
\hline \multicolumn{5}{|l|}{ Domestic } \\
\hline $\begin{array}{l}\text { Household } \\
\quad(\mathrm{HH})\end{array}$ & 657,769 & $93 \%$ & 200 & $\begin{array}{l}36 \mathrm{HH} \text { of low economy }(17.84 \%) \\
62 \mathrm{HH} \text { of mid-class economy }(30.83 \%) \\
102 \mathrm{HH} \text { of high-class economy }(51.32 \%)\end{array}$ \\
\hline \multicolumn{5}{|l|}{ Nondomestic } \\
\hline Schools & 2,113 & $80 \%$ & 25 & $\begin{array}{l}1 \text { public kindergarten and } 5 \text { private kindergartens }(24.8 \%) \\
10 \text { public elementary schools and } 2 \text { private elementary } \\
\text { schools }(46.81 \%) \\
1 \text { public junior high school and } 2 \text { private junior high } \\
\text { schools }(10.13 \%) \\
1 \text { public senior high school and } 1 \text { private senior high school } \\
(6.39 \%) \\
1 \text { public vocational school and } 1 \text { private vocational school } \\
(6.25 \%) \\
1 \text { public university and } 1 \text { private university }(5.63 \%)\end{array}$ \\
\hline Offices & 6,310 & $80 \%$ & 25 & $\begin{array}{l}\text { Government office } \\
\text { Private office } \\
\text { Government-owned enterprise }\end{array}$ \\
\hline Laundromats & 750 & $80 \%$ & 25 & $\begin{array}{l}\text { Population is predicted, no specific categorization in } \\
\text { samples }\end{array}$ \\
\hline TOTAL & & & 275 & \\
\hline
\end{tabular}

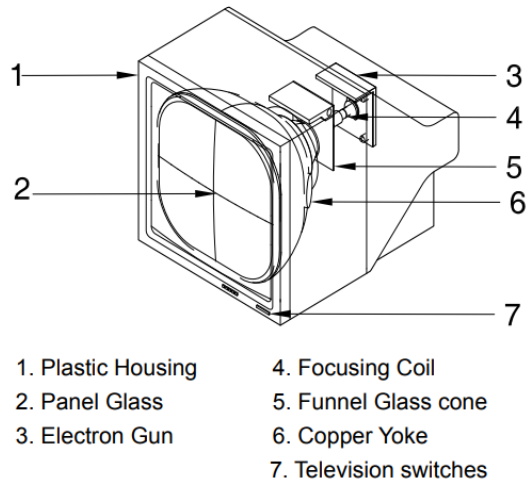

Fig. 1. Components of a CRT monitor.

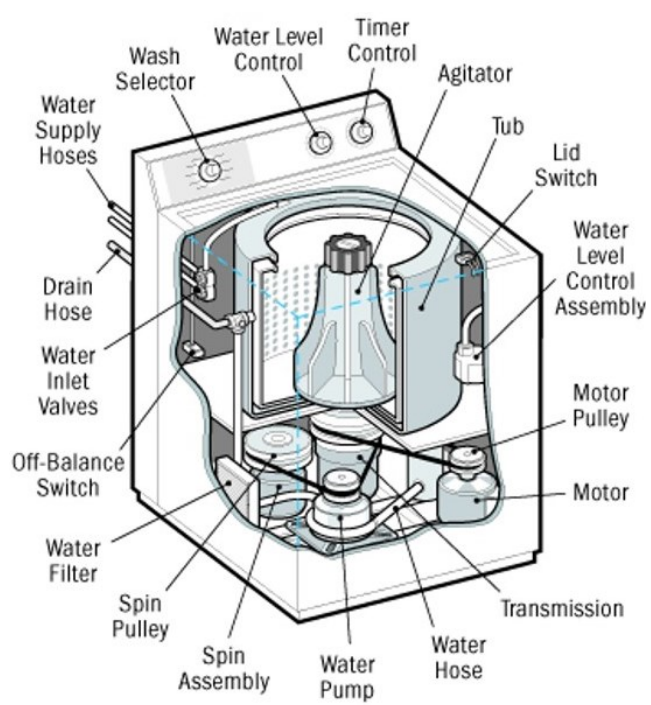

Fig. 2. Components of a washing machine.

\section{Results}

\subsection{Survey derived data}

Survey results hint that the use of CRT TVs and CRT monitors show a rise in the 90 s era, and reached its peak in the early $21^{\text {st }}$ century. Between the period of $2007-$ 2010, the trend for those e-products have drastically declined (mass disposal) and continues to diminish, especially in nondomestic sectors (schools and offices) due to the introduction of new and improved technology that is flat screens. Although the nondomestic units tend to follow the technology trend, many households still own or use CRT TVs and CRT monitors, especially in low and middle-class economy households. The trend for CRT TV and CRT monitor sales are heading towards zero. Even most offices have already gotten rid of such products so that the e-waste generation also declines within these past couple of years.

The only difference in consumption trends are found in that of washing machines, specifically from households and laundromats. Unlike CRT products, washing machines have not been replaced with any new technology so that the use of washing machines within our society is still normal, if not increasing in demand. The prediction of waste CRT products cannot be done with a period of time that is too long because consumption is declining rapidly (until it may reach zero altogether), meanwhile the prediction of waste washing machines has to take into account the trend of sales and higher levels of consumption. Table 2 summarizes the average e-waste generated in Bandung. 


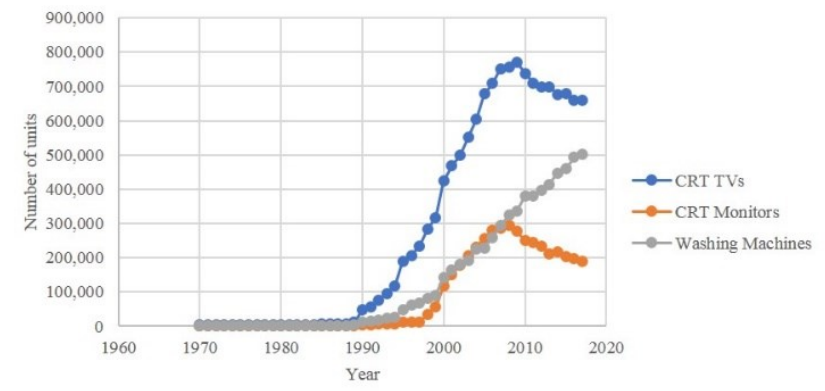

(a)

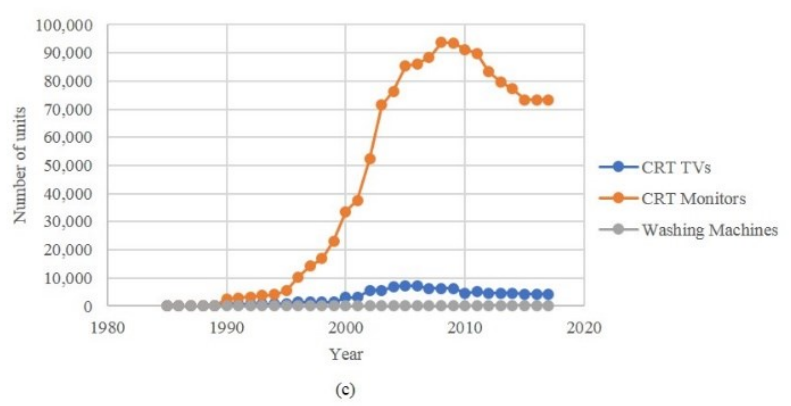

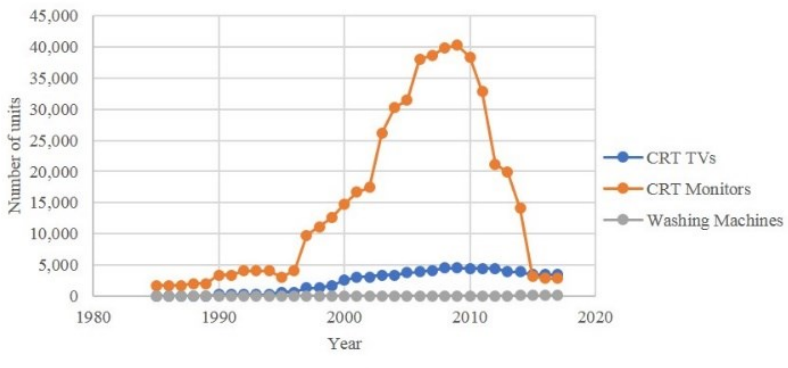

(b)

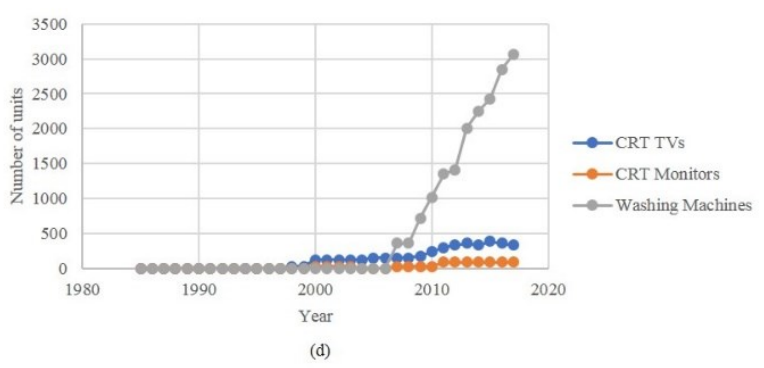

Fig. 3. Trend of CRT TVs/monitors and washing machines possessions in Bandung; (a) households, (b) schools, (c) offices, (d) laundromats.

Table 1. Average amount of e-waste generated annually in Bandung.

\begin{tabular}{|c|c|c|c|}
\hline \multirow{2}{*}{ Source of E-waste } & \multicolumn{3}{|c|}{$\begin{array}{c}\text { Average e-waste generated per } \\
\text { year (units/year) }\end{array}$} \\
\hline & $\begin{array}{l}\text { CRT } \\
\text { TVs }\end{array}$ & $\begin{array}{c}\text { CRT } \\
\text { Monitors }\end{array}$ & $\begin{array}{l}\text { Washing } \\
\text { Machines }\end{array}$ \\
\hline $\begin{array}{l}\text { Household } \\
(\mathrm{n}=200 ; \mathrm{N}=657,769)\end{array}$ & 22,827 & 16,615 & 15,260 \\
\hline $\begin{array}{l}\text { Schools } \\
(n=25 ; N=2,113)\end{array}$ & 261 & $3,978.4$ & $\sim$ \\
\hline $\begin{array}{l}\text { Offices } \\
(n=25 ; N=6,310)\end{array}$ & 662.6 & $3,821.1$ & $\sim$ \\
\hline $\begin{array}{l}\text { Laundromats } \\
(\mathrm{n}=25 ; \mathrm{N}=750)\end{array}$ & $\sim$ & $\sim$ & 80 \\
\hline
\end{tabular}

The generation of waste CRT products from laundromats can be ignored because consumption of such products is very insignificant compared to the consumption in other sources of e-waste. The same applies to waste washing machines from schools and offices.

Because the prediction of e-waste generation depends on a life-cycle analysis, then another objective of the survey is to determine the lifespan and shelf life (period of storage) of CRT TVs, CRT monitors and washing machines. Lifespan is defined by the period of time in which the electronic product is still in use, which is calculated from the time of purchase until the time of defection or the time it becomes obsolete. Shelf life is defined as the period of time during which time the product has already passed its lifespan, but is still kept in storage and not yet disposed of. The following equations will better define such terms;

$$
L_{u}=t_{o}-t_{p}
$$

$$
L_{s}=t_{d}-t_{o}
$$

whereas

$L_{u} \quad=$ lifespan of product (years),

$L_{s} \quad=$ shelf or storage life of product (years),

$t_{p} \quad=$ year of product purchase,

$t_{o} \quad=$ year of defection or obsolescence, and

$t_{d} \quad=$ year of disposal.

Survey results show that the life span and shelf or storage life varies with each product. The data obtained also gave a wide range of variety in such numbers within the same product category. This is mainly due to the fact that the condition of the electronic product, whether new or secondhand, upon purchasing was not considered. Table 2 and Table 3 summarizes the average life span and storage life of CRT TVs, CRT monitors, and washing machines that were obtained from survey data.

The life span of electronic products given in Table 3 shows numbers smaller in households of lower class economy, meanwhile the life span of e-products in households of middle and high-class economy are of approximately the same value. This statement follows the results of Widyarsana's [4] research of e-waste generation in Bandung, 2005-2006, which shows that residents of lower-class economy households tend to buy secondhand products, whose life span is shorter than new products. On the other hand, new products are more favorable to higher economy households, which is why the life span is longer. According to Widyarsana [4], an approximate $40 \%$ of low economy households prefer to buy secondhand electronics, meanwhile only $10 \%-20 \%$ of high-class economy households use secondhand electronics. 
Table 2. Average life span of CRT TVs, CRT monitors and washing machines according to survey results.

\begin{tabular}{lccc}
\hline \multirow{2}{*}{ Source of E-waste } & \multicolumn{3}{c}{ Life Span (years) } \\
\cline { 2 - 4 } & $\begin{array}{c}\text { CRT } \\
\text { TVs }\end{array}$ & $\begin{array}{c}\text { CRT } \\
\text { Monitors }\end{array}$ & $\begin{array}{c}\text { Washing } \\
\text { Machines }\end{array}$ \\
\hline $\begin{array}{l}\text { Domestic } \\
\text { HH of high-class } \\
\text { economy }\end{array}$ & 9.57 & 6.08 & 8.27 \\
$\begin{array}{l}\text { HH of middle-class } \\
\text { economy }\end{array}$ & 9.53 & 5.48 & 9.11 \\
$\begin{array}{l}\text { HH of lower-class } \\
\text { economy }\end{array}$ & 8.03 & 4.13 & 4.78 \\
$\begin{array}{l}\text { Nondomestic } \\
\text { Schools }\end{array}$ & & & \\
$\begin{array}{l}\text { Offices } \\
\text { Laundromats }\end{array}$ & 9.3 & 8 & $\sim$ \\
\hline
\end{tabular}

Table 3. Average storage life of CRT TVs, CRT monitors and washing machines according to survey results.

\begin{tabular}{lccc}
\hline \multirow{2}{*}{ Source of E-waste } & \multicolumn{3}{c}{ Storage Life (years) } \\
\cline { 2 - 4 } & $\begin{array}{c}\text { CRT } \\
\text { TVs }\end{array}$ & $\begin{array}{c}\text { CRT } \\
\text { Monitors }\end{array}$ & $\begin{array}{c}\text { Washing } \\
\text { Machines }\end{array}$ \\
\hline $\begin{array}{l}\text { Domestic } \\
\text { HH of high-class } \\
\text { economy }\end{array}$ & 2.52 & 2.37 & 0.66 \\
$\begin{array}{l}\text { HH of middle-class } \\
\text { economy }\end{array}$ & 0.86 & 2.39 & 1.15 \\
$\begin{array}{l}\text { HH of lower-class } \\
\text { economy }\end{array}$ & 0.86 & 0.88 & 1.12 \\
$\begin{array}{l}\text { Nondomestic } \\
\text { Schools }\end{array}$ & & & \\
$\begin{array}{l}\text { Offices } \\
\text { Laundromats }\end{array}$ & 1.95 & 2.14 & $\sim$ \\
\hline
\end{tabular}

Data on storage life also corresponds to Widyarsana's [4] research, in that electronics purchased as new products are kept in storage for longer periods of time than secondhand electronics. According to survey results, with the assumption that a larger portion of low economy households use secondhand electronics, the storage life is then shorter than that of the electronics purchased in new conditions by households of higher class economy.

\subsection{E-waste generation prediction}

Data on current e-waste generation given by survey results need to be further analyzed to predict the e-waste generation in the upcoming years. The e-waste generation cannot be directly predicted from the previous trend data because the trend for e-waste disposal does not show a general pattern, but a quite random trend.

From the survey, we can conclude that the purchase of CRT TVs and CRT monitors have nearly come to zero since 2015 in households and schools, and further since 2012 in offices due to the shift to flat screen displays. For unprofessional use, CRT TVs and CRT monitors are still popular in households, either as old appliances or stored and waiting to be disposed of. Nevertheless, purchase of new CRT products are still declining sharply. Therefore, the prediction of waste CRT products generation will simulate the diminishing of said products until it reaches complete elimination throughout Bandung. With the assumption that there will be no more CRT TVs and CRT monitors purchased in the coming years, the future ewaste generation is predicted from the existing number of electronic products that are already in use in Bandung, and disposal is calculated according to life span and storage life already given in Table 3 and Table 4.

As stated before, the prediction of waste washing machine generation cannot depend only on the existing number already used in Bandung, but rather with the consideration of future sales trends. Sales trends are projected from the existing trend of sales from mid 1980s to present day. Though the trend fluctuates, the trend for washing machine sales can be summarized generally to show a positive inclination. These trends (of washing machine possessions and sales) can be graphically presented by Figure 4 and Figure 5 .

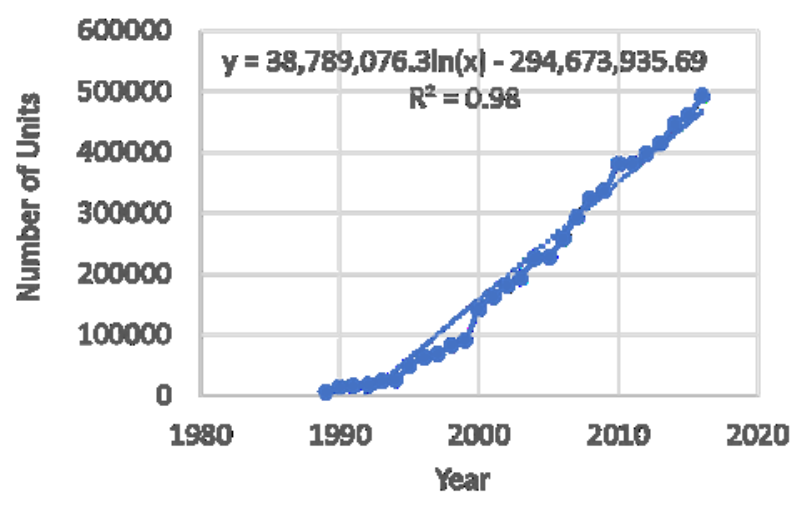

(a)

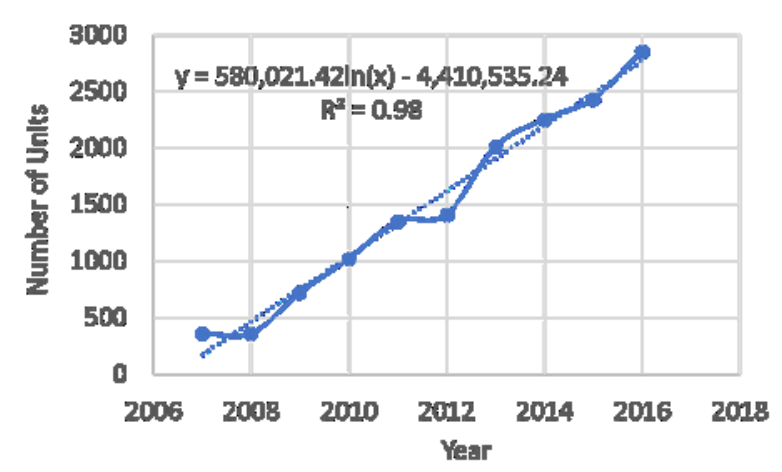

(b)

Fig. 4. Trend of washing machine possessions in Bandung; (a) households, (b) laundromats.

A logarithmic trend is used because electronic products follow a 4-step life cycle, from introduction of product, to rapid growth, a stagnant trend and ending with a rapid decline. Derived from the graphics in Figure 4, the number of washing machines accumulated is given by Equation 3 and Equation 4 respectively for households and laundromats. 


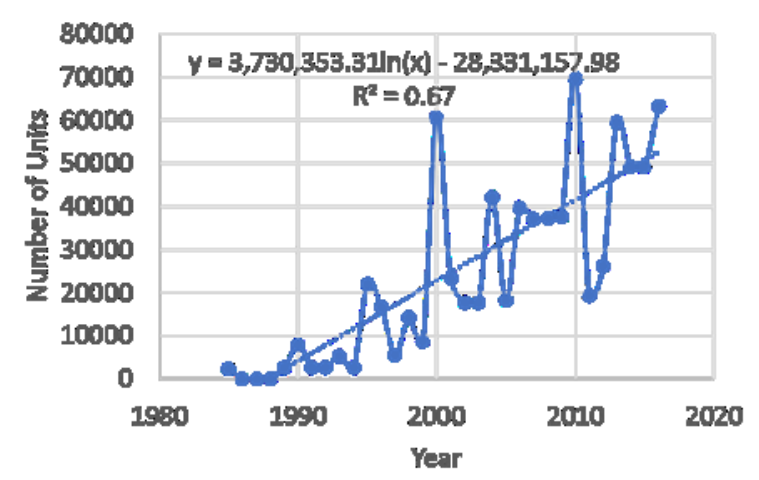

(a)

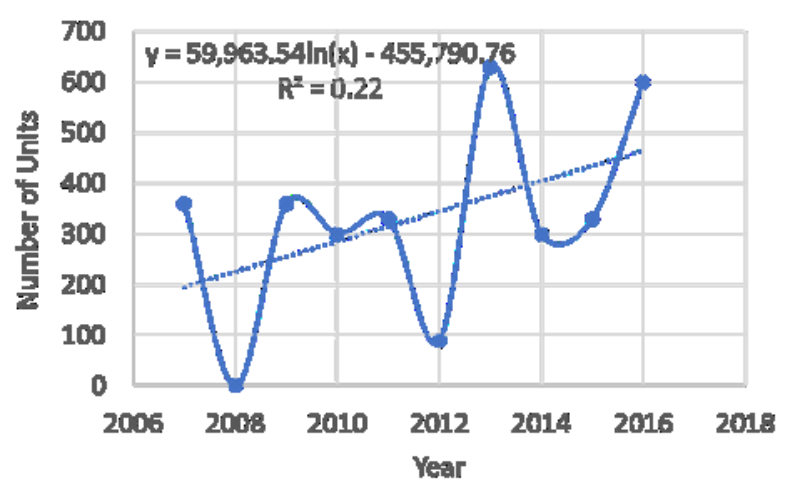

(b)

Fig. 5. Trend of washing machine sales in Bandung; (a) households, (b) laundromats.

$$
\begin{gathered}
y_{a H H}=(38,789,076.3 \times \ln (x))-29,673,935.69 \\
y_{a L}=(580,021.42 \times \ln (x))-4,410,535.24
\end{gathered}
$$

whereas

$y_{a H H}=$ accumulation of washing machines owned in households in year $\mathrm{x}$,

$y_{a L}=$ accumulation of washing machines owned in laundromats in year $\mathrm{x}$, and

$x=$ year of study.

The following equations are used to determine the number of washing machine sales, derived from Figure 5.

$$
\begin{gathered}
y_{s H H}=(3,730,353.31 \times \ln (x))-28,331,157.98 \\
y_{s L}=(59,963.54 \times \ln (x))-455,790.76
\end{gathered}
$$

whereas

$$
\begin{aligned}
y_{s H H}= & \text { number of sales/purchase of washing } \\
& \text { machines from households in year } \mathrm{x}, \\
y_{s L}= & \text { number of sales/purchase of washing } \\
& \text { machines from laundromats in year } \mathrm{x}, \text { and } \\
x \quad= & \text { year of study. }
\end{aligned}
$$

Meanwhile, the number of discarded washing machines is determined with the following equation.

$$
D_{n}=A C_{n-1}+S P_{n}-A C_{n}
$$

whereas

$D=$ disposal of waste washing machine,

$A C=$ accumulation of washing machines owned,

$S P=$ sales/purchase of washing machines, and $n \quad=$ year of study.

The prediction of e-waste generation is done per year, which is then used to determine the annual average as follows:

- Waste CRT TVs as many as 65,195 units/year

- Waste CRT monitors as many as 19,191 units/year

- Waste washing machines as many as 47,987 units/year.

For a number of households of approximately 650,000 units, the prediction shows that within 10 years, almost every household will discard a single CRT TV and washing machine, and as many as 0.3 units of CRT monitors. This is a relatively high number, considering a desktop possession coefficient of 0.57 in Bandung in 2008 as stated by Widyarsana [4]. Widyarsana [4] also predicted that by 2015 , as much as 2,000 tons/year worth of computer waste will be generated, which can be estimated to 100,000 units (for an average weight of 20 $\mathrm{kg}$ as stated by Huisman [2]). The difference found in Widyarsana's [4] studies are probably due to the different survey methods --Widyarsana [4] not only studied the waste generation from domestic and nondomestic units, but also the informal sectors that play different roles in ewaste collection and management-- and that this prediction applies for both CRT and flat screen computers. Referencing to other Asian countries such as China, with a household population of about 450 million in 2012, Singh [3] stated that by 2012, it is estimated that around 190 million PCs and 74 million TVs will become obsolete, with CRTs making up of around $80 \%$ of the number. In a study by Yoshida [5] the annual amount of e-waste generated in Indonesia, the Philippines and Vietnam (all of which are categorized as middle-income countries) ranged from 2 to $3 \mathrm{~kg}$ per capita. Assuming one household holds 4-5 people, then the household generation is estimated to $15 \mathrm{~kg}$ per year. Yoshida's [5] study result gives a rather small number in comparison to the numbers given by this study.

\section{Conclusion}

Based on the survey study done, it can be concluded that waste CRT products will diminish within the next decade, if an integrated waste collection and recycling system is implemented in Bandung. The number of waste CRT products can be summed (from TVs and monitors) to 74,000 units/year, meanwhile the number of waste washing machines generated is estimated to be around 48,000 units/year.

\section{References}

1. J.R. Gregory, M.C. Nadeau, R.E. Kirchain, Env. Sci. \& Tech., 43(24), 9245-9251 (2009)

2. J. Huisman, F. Magalini, R. Kuehr, R., C. Maurer, C. Delgado, E. Artim, J. Szlezak, S. Oglivie, J. Poll, A. Stebels, 2008 Review of directive 2002/96 on waste electrical and electronic equipment (WEEE) final report (United Nations University, Germany, 2007)

3. N. Singh, J. Wang, J. Li, Procedia Env. Sciences, 31(2016), 465-474 (2016) 
4. I.M.W. Widyarsana, I.M.W. Pengembangan metode proyeksi timbulan limbah "e-waste" berdasarkan masa pakai (end-of-life) barang "e-product" sebagai dasar dalam prediksi material flow analysis (MFA), Disertation. Environmental Engineering Program, Faculty of Civil and Environmental Engineering, Bandung Institute of Technology, Bandung (2008)

5. A. Yoshida, A. Terazono, F.C Jr. Ballesteros, D. Nguyen, S. Sukandar, M. Kojima, S. Sakata, Res. Cons. and Rec., 106(2016), 48-58 (2015) 